\title{
Ergonomic Checkpoint in Agriculture, Postural Analysis, and Prevalence of Work Musculoskeletal Symptoms among Indonesian Farmers: Road to Safety and Health in Agriculture
}

\begin{abstract}
Ari Widyanti ${ }^{1 *}$
Abstract: Agriculture is one of the most crucial and hazardous sectors in both the developing and the developed countries. The agriculture area has a various problem related to safety and health, calling an urgent research to solve the problem. The purpose of this study is to apply ergonomics checkpoint in agriculture (developed by ILO) in Indonesian as well as to observe the prevalence of musculoskeletal symptoms among Indonesian farmers. Two hundreds fifty one Indonesian farmers participate voluntarily in this study. "Ergonomic checkpoint in agriculture" as a tool to reduce agriculture-related accident and increase productivity is assessed by student researcher. Prevalence of musculoskeletal symptoms (MSS) is assessed using Nordic body map that is filling out by participants. Rapid Upper Limb Assessment (RULA), Rapid Entire Body Assessment (REBA), and postural analysis using three dimensions Static Prediction Program (3D SSPP) are applied to observe the risk activities of Indonesian farmers including the manual hoe for land clearing, grass cutting for land clearing, planting the rice, manual plow, giving fertilizer, harvesting, threshing, cleaning the rice from the straw, and sun-drying of rice. According to ergonomics checkpoints, material handling and storage are the worst in Indonesian agriculture, coupled with minimum safety information, toilet and washing facilities, and first aid. The highrisk activities are manual hoe for land clearing, manual plow, grass cutting for land clearing and threshing. The reported MSS mainly found in the shoulder and lower back. In conclusion, Indonesian agriculture is in a poor ergonomics condition and is associated with high musculoskeletal symptoms. The postural analysis also reveals a high risk of farmer activities.
\end{abstract}

Keywords: Indonesian, farmer, musculoskeletal symptom, 3D SSPP, RULA, REBA.

\section{Introduction}

Agriculture is one of the most crucial sectors in both the developing and the developed countries since it ensures the food security of the country (see Widyanti et al., [1] for an example) and gives a significant contribution to the gross domestic product of a country. In contrast, agriculture is also one of the most hazardous industries. The hazard found in agriculture sectors triggers a various problem, ranging from psychosocial factors, health problems (i.e., malnutrition, underweight), stress, musculoskeletal disorder (Susanto [2]) and injury while using agriculture tools or equipment (Fallahi et al. [3]).

Among the various problem found in agriculture mentioned above, a problem commonly reported in agricultural workers in particular farmers in a rural area is work-musculoskeletal symptoms (MSS) in a different part of a body.

\footnotetext{
1 Faculty of Industrial Technology, Department of Industrial Engineering, Institut Teknologi Bandung, Labtek III, Jl. Ganesha 10, Bandung 20342, INDONESIA.

Email: widyanti@mail.ti.itb.ac.id

* Corresponding author
}

The MSS, in the end, will affects cumulative musculoskeletal disorders as well as an accident (see Susihono [4] for an example). In fact, there is a large body of evidence from many countries about workrelated musculoskeletal disorders among farmers. For instance, National Institute for Occupational Safety and Health (NIOSH [5]) has described disorder of the back and neck, nerve entrapment syndromes, and musculoskeletal disorders such as tendinitis among US farmers. Other study conducted by Helkamp and Lundstrom [6]; Davis and Kotowski [7] described the fact that farmers' injuries in the US are higher than injuries in workers' industry due to low infrastructure conditions and the unstandardized of work condition and worker requirement. Min et al. [8] described similar problem among Korean farmers. Whereas in developing country, Singh and Arora [9] and Oja and Kwatra [10] also reported health problem among Indian farmers. Similar problems were also reported among Nigerian farmers (Tella et al. [11]).

In general, MSS is associated with three main risk factors that are the force, repetition, and awkward postures. One of or combination of these factors may contribute to the development of MSS. The MSS 
among farmers might due to activities of the farmer that is dominated by manual activities in every process of farming, start from the plantation to harvest. These activities are a combination of excessive force, repetitive work, and awkward postures of the farmer during performing their activities on the farm. Specifically, Meyers et al. [12] mentioned three activities in farming that require improvement, are lifting an carrying heavy loads, repeated full-body bending, and high repetitive handwork (e.g., cutting etc).

Attention has been given in agricultural settings to help reduce work-related accident, illness, and injury, as well as improve working and living condition and increase productivity. One approach that can be applied in order to gain those objectives is ergonomics. Ergonomics is the study of work, in particular study of human capability and limitation for design purpose, to make the work fit the worker (Grandjean, [13]). The ultimate goal of the ergonomics application is to prevent health problem and accident and to increase productivity. In addition, Kirkhorn et al. [14] underlined the association of ergonomics risk factors and MSS. More importantly, research has shown that ergonomics approach can reduce risk factors in agriculture (e.g., Singh and Arora [9]).

Considering the importance of ergonomics in agriculture, International Labor Organization (ILO) in collaboration with International Ergonomics Association (IEA) developed ergonomics approach to improve safety and health in agriculture, named ergonomics checkpoints for agriculture. In general, the ergonomic checkpoint is compiling practical hints as a means of improving workplace conditions from ergonomics points of view. This checkpoint has been found to be useful in reducing ergonomics-related risk in different work settings (Kawakami and Kogi, [15]). In particular related to ergonomics checkpoint in agriculture, Budnizk et al., [16] reviewed its implementation in developing countries, and more specifically, Kogi [17] described success implementation of the checkpoint in Japanese agriculture.

Beside ergonomic checkpoint for agriculture, ergonomics approach that can be used in analyzing postural work is occupational biomechanics approach. The occupational biomechanics can be defined as the study of the physical interaction of workers with their tools, machines, and materials so as to enhance the workers' performance while minimizing the risk of musculoskeletal disorders (Chaffin et al. [18]). Assessment of biomechanical approach can be conducted both subjectively (i.e, based on perceived of subjects) and objectively (i.e., using quantitative method and tools).
One biomechanic tool for assessing MSS subjectively is the Nordic body map questionnaire, developed by the Institutes of Occupational Health in the Nordic countries (Kourinka [19]). This tool has been widely used not only in Nordic countries but also in all over the world. The Nordic body map equipped with a map of the body with a number of each part of the body. The assessed people must fill in the Nordic questionnaire by giving a mark on the level of discomfort in the intended body part. Other tools are Rapid Entire Body Assessment (REBA, Hignett and MacAtamney [20]) and Rapid Upper Limb Assessment (RULA, McAtamney and Corlett, [21]). Both REBA and RULA used several tables in assessing biomechanical load of part of human body.

One objective tool for assessing occupational biomechanics is the three dimensions static strength prediction program (3D SSPP software, Univ of Michigan [22]). The 3D SSPP is a software that can be used to predict static strength requirements for tasks such as lifts, presses, pushes, and pulls. The analysis is aided by an automatic posture generation feature and three-dimensional human graphic illustrations.

Indonesia is one of the biggest agricultural countries. Recently, 38 million Indonesian people (about $40 \%$ of total Indonesian workforce) work in agricultural industries, including farm labor, smallholder farmers, or worker in the agro-industrial plantation (Indonesian statistical bureau, BPS [23]). The agriculture workers in Indonesia can be divided as agricultural household work the land themselves, farm household works the land with the wage distribution of agricultural products, and the agricultural household work land people paid with the money (Wibowo and Sony, [24]). The most important thing that must be highlighted is that the agricultural sector is the highest source of commodity exports from Indonesia and give the biggest contribution to Indonesian Gross Domestic Product (BPS [23]).

Considering the importance of agriculture for Indonesia, unfortunately, research related to agriculture in Indonesia is very limited. Most of the limited research in Indonesian agriculture falls into the category of the design of tools (e.g., Wibowo and Soni, [24]). Considering the widely reported of workrelated musculoskeletal symptoms and disorders in agriculture internationally which in the end influence agricultural' productivity, it is likely that similar problem also experiences by Indonesia agriculture and Indonesian farmers. Therefore, there is an urgent need to observe ergonomics conditions in Indonesian agriculture and prevalence of musculoskeletal injuries among Indonesian farmers. 
The information will be valuable to improve Indonesian agriculture condition, not only to increase productivity but also to reduce the most likely accident and injury in Indonesian agriculture. As stated by Fuglie [25], Indonesian total food productivity has been increased since 1960. In particular for rice, Indonesia and Vietnam were ahead in average rice yields in 2012-2014. However, recently, there is a productivity slowdown in Indonesian agriculture due to several reasons, one of them is the lack of productivity enhancement' efforts.

The purpose of this study is to apply ergonomic checklist for agriculture in Indonesian farmers as suggested by $\mathrm{LO}$ [26] as an effort to increase Indonesian agricultural safety as well as productivity. In addition, this study also observes the prevalence of musculoskeletal symptoms among Indonesian farmers using the Nordic body map, as well as RULA or REBA if applicable due to its nature of farmer' activities. To strengthen the analysis, postural analysis using 3D SSPP was conducted to examine the real load of rice farming activities, since the first two methods (ergonomics checklist, Nordic body map, RULA or REBA) is assessed by the observer and based on perceived symptoms that might not free from subjective bias.

\section{Methods}

\section{Participants}

Two hundred and fifty-one Indonesian farmers live in West Java province, Indonesia, participate voluntarily in this study (mean age $=51$ years, $\mathrm{SD}=13$ years, 105 female). The sample is chosen using convenience sampling method.

\section{Procedure}

Ergonomic checkpoint in agriculture (ILO [26]) is assessed by student research assistant who has prior knowledge and short training in using the checklist. This checkpoint is used to observe the ergonomic condition of Indonesian agriculture and farmer. The original ergonomic checkpoint consists of 100 items, including these factors: storage and handling of materials, workstations and tools, machine safety, agriculture vehicle, physical environment, control of hazardous chemicals, environmental protection, welfare facilities, family and community cooperation, work organization and working schedules. However, as suggested by ILO, considering practical and representativeness of the real condition of farming, 30-40 items represents intended dimensions is considered to be appropriate. Coupled with similarity of agricultural condition of farming between
Indonesia and Malaysia, the ergonomics checkpoints for agriculture consist of 31 items provided by National Institute of Occupational Safety and Health Malaysia (in ILO [26]) is used in this study including 7 items of storage and handling of materials, 5 items of workstations and tools, 3 items of machine safety, 7 items of work environment and control of hazardous agents, 6 items of welfare facilities, and 3 items of work organization.

The Nordic body map is given to the participants to be filling out with an assist of student research assistant when needed. However, due to practical reason, most participants are semi structure-interviewed by student research assistant. The Nordic body map consists of 28 part of the body that must be rated based on the symptoms. Examples of the body parts are the right shoulder, upper arm, etc. REBA analysis is based on 3 different tables that observe load, coupling, and activity score. The final score of REBA can be categorized based on risk level. Example of REBA analysis can be seen in http://ergo.human.cornell. edu/ahReba.html.

Almost similar with REBA, RULA uses several tables that are used to examine the risk level: $1^{\text {st }}$ table for arm and wrist analysis; the $2^{\text {nd }}$ table for the neck, trunk, and leg analysis; and the $3^{\text {rd }}$ table for mapping result of $1^{\text {st }}$ and $2^{\text {nd }}$ table. An example of RULA analysis can be seen in http://www.rula.co.uk/.

3D SSPP is used in the postural analysis of Indonesian farmers. The static posture is obtained from the breakdown of task analysis based on principal activities of Indonesian farmer during rice farming. Rice farming has used a base of analysis since rice is the staple food of Indonesian and most of the Indonesian farmer plant this commodity. The step of rice farming, in general, can be divided by pre-planting, growth, and post-production (international rice research institute, IRRI [27]). Pre-planting activities involve choosing the right variety, developing a cropping calendar, and preparing the rice field for planting. Growth activities include planting method, water, fertilizer, weeds, and pests and diseases. Pots of production include harvesting and after harvesting. After harvesting, the rice paddy undergoes postharvest processes including drying, storage, and milling to ensure good eating quality and marketability.

\section{Results and Discussions}

\section{Ergonomics Checkpoints}

Ergonomic checkpoint of Indonesian farmers can be seen in Table 1. The percentage of "No" answer is 
Table 1. Ergonomic checkpoint of Indonesian farmers (source: www.ILO.com)

\begin{tabular}{|c|c|c|c|}
\hline Description & Yes $(\%)$ & No $(\%)$ & N/A $(\%)^{*}$ \\
\hline \multicolumn{4}{|l|}{ Material storage and handling } \\
\hline $\begin{array}{l}1 \text { The passageways are clear and in good condition for the movement of people and } \\
\text { materials. }\end{array}$ & 33.1 & 66.9 & 0.0 \\
\hline No sudden height differences and holes on transport routes & 42.2 & 57.8 & 0.0 \\
\hline $\begin{array}{l}3 \text { The bridges over canals or over ditches at the edge of the filed or road are wide enough } \\
\text { and stable }\end{array}$ & 44.2 & 41.4 & 14.3 \\
\hline $\begin{array}{l}4 \text { The multi-level shelves or racks are available near the work area for storing materials, } \\
\text { tools or products }\end{array}$ & 32.3 & 40.2 & 27.5 \\
\hline $\begin{array}{l}5 \text { Containers or baskets of appropriate sizes and with good grips are available to carry } \\
\text { materials and farm products. }\end{array}$ & 33.9 & 56.6 & 9.6 \\
\hline Charts, hand trucks, vehicles, boats, or animals to carry heavy materials are available. & 26.7 & 66.5 & 6.8 \\
\hline $\begin{array}{l}7 \text { There are large enough wheels to carts and hand trucks to work effectively on field } \\
\text { routes. }\end{array}$ & 23.9 & 53.4 & 22.7 \\
\hline \multicolumn{4}{|l|}{ Workstation design and work tools } \\
\hline $\begin{array}{l}8 \text { The work height to do that work is adjusted at elbow level or slightly lower than elbow } \\
\text { level. }\end{array}$ & 42.6 & 25.5 & 31.9 \\
\hline 9 Stable chairs or benches with sturdy backrests are provided. & 28.7 & 39.4 & 31.9 \\
\hline $\begin{array}{l}10 \text { The frequently used tools, switches and materials are located within easy reach of } \\
\text { farmers }\end{array}$ & 71.7 & 8.8 & 19.5 \\
\hline 11 A "home" for each tool is provided. & 51.0 & 45.0 & 4.0 \\
\hline 12 Jigs, clamps, or other fixtures to hold items while work is done are used. & 7.6 & 47.4 & 45.0 \\
\hline \multicolumn{4}{|l|}{ Machine safety } \\
\hline 13 Proper guards to dangerous moving parts of machines are attached. & 41.8 & 11.6 & 46.6 \\
\hline 14 Appropriate feeding devices to avoid danger and increase production are used. & 34.7 & 12.0 & 53.4 \\
\hline $\begin{array}{l}15 \text { The emergency controls are made to be clearly visible and attach local language labels } \\
\text { to the controls or switches are provided }\end{array}$ & 15.5 & 15.5 & 68.9 \\
\hline \multicolumn{4}{|l|}{ Work environment and control of hazardous agents } \\
\hline 16 Natural ventilation to improve the indoor climate is applied & 66.1 & 6.4 & 27.5 \\
\hline 17 Daylight and bright walls for lighting up the workplace are used & 74.9 & 3.2 & 21.9 \\
\hline 18 Continuous exposure to excessive heat or cold is avoided & 43.4 & 39.0 & 17.5 \\
\hline $\begin{array}{l}19 \text { Pesticides, agrochemicals and spraying devices are located in a safe and designated } \\
\text { place }\end{array}$ & 68.1 & 21.9 & 10.0 \\
\hline 20 Pesticides and agrochemicals are given appropriate labels. & 56.2 & 29.1 & 14.7 \\
\hline $\begin{array}{l}21 \text { Safety and health information, such as the safe use of agrochemicals, and disseminate } \\
\text { the information to the community are collected. }\end{array}$ & 39.0 & $\mathbf{5 7 . 0}$ & 4.0 \\
\hline 22 Animals, insects or worms that may harm farmers are given appropriate awareness. & 90.0 & 10.0 & 0.0 \\
\hline \multicolumn{4}{|l|}{ Welfare facilities } \\
\hline 23 An adequate supply of drinking water and refreshment at the farm is provided & 68.5 & 31.5 & 0.0 \\
\hline 24 Clean, hygienic toilets and washing facilities is available & 18.3 & 74.5 & 7.2 \\
\hline 25 Resting corners and facilities for recovery from fatigue are provided. & 51.0 & 47.8 & 0.8 \\
\hline $\begin{array}{l}26 \text { Proper protective devices such as clothes, gloves, boots, shoes, hats, helmets to protect } \\
\text { from injuries or contact with hazardous substances are used. }\end{array}$ & 65.7 & 30.7 & 3.6 \\
\hline 27 First-aid equipment are provided. & 19.5 & 64.1 & 16.3 \\
\hline 28 Pregnant women and farmers with disabilities are treat with special care. & 39.0 & 31.1 & 29.9 \\
\hline \multicolumn{4}{|l|}{ Work organization } \\
\hline 29 There is a better work layout to reduce the distance for carrying materials & 41.4 & 47.0 & 11.6 \\
\hline 30 There are frequent short breaks & 50.2 & 49.4 & 0.4 \\
\hline $\begin{array}{l}31 \text { There are share family responsibilities to avoid overburdening a particular family } \\
\text { member }\end{array}$ & 69.3 & 23.5 & 7.2 \\
\hline
\end{tabular}

- N/A option is due to restriction in its applicability and its relevant to local condition

higher than "Yes" answer, indicates poor ergonomics condition in a sample of Indonesian farmers. Based on the highest percentage of "No" answer, it can be concluded that Indonesian farmers are in need of improvement and need of intervention to obtain safe and health agriculture conditions.

\section{Prevalence of Musculoskeletal Symptoms/ Disorder}

Prevalence of musculoskeletal symptoms/disorder among the sample of Indonesian farmers can be seen in Table 2. 
Table 2. Prevalence of musculoskeletal symptoms/disorder among sample of Indonesian farmer

\begin{tabular}{lcccc}
\hline \multirow{2}{*}{ Part of the body } & \multicolumn{2}{c}{ Experience of symptoms (\%) } & \multicolumn{2}{c}{ Are the symptoms related with farm works? (\%) } \\
\cline { 2 - 5 } & Yes & No & Yes & No \\
\hline Neck & 58.6 & 41.4 & 77.3 & 22.7 \\
Shoulder & 76.1 & 23.9 & 76.5 & 23.5 \\
Elbow & 53.0 & 47.0 & 75.3 & 27.7 \\
Wrist & 60.6 & 39.4 & 72.9 & 22.3 \\
Upper back & 62.9 & 37.1 & 77.7 & 17.9 \\
Lower back & 74.9 & 25.1 & 82.1 & 26.7 \\
Thigh & 61.0 & 39.0 & 73.3 & 21.9 \\
Knee & 65.3 & 34.7 & 72.5 & 27.5 \\
Ankle & 51.0 & 49.0 &
\end{tabular}

The highest percentage of the reported MSS are in the shoulder, lower back, knee, upper back, thigh, and wrist.

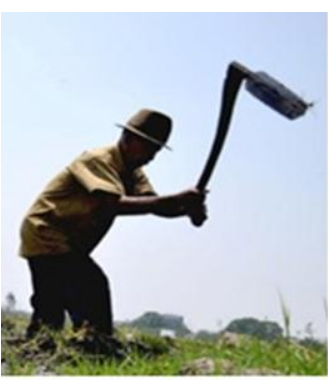

(a)

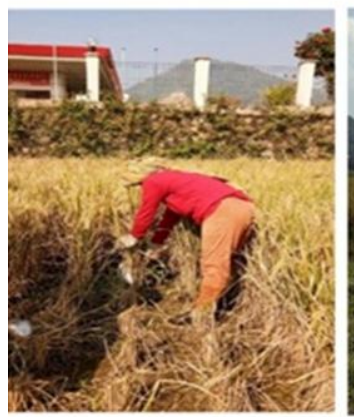

(f)

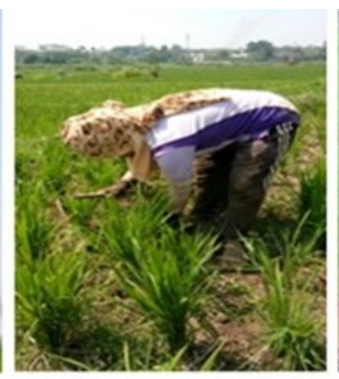

(b)

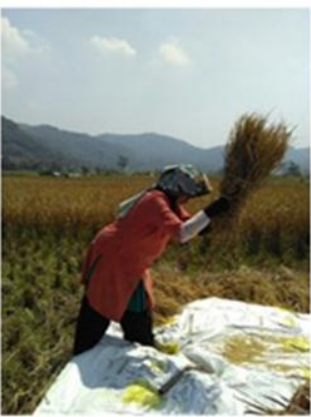

(g)

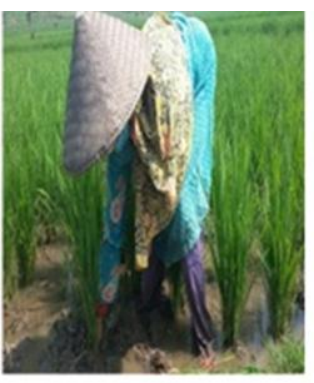

(c)

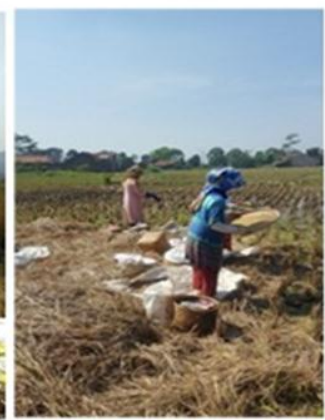

(h)

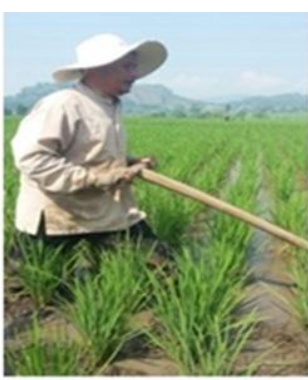

(d)

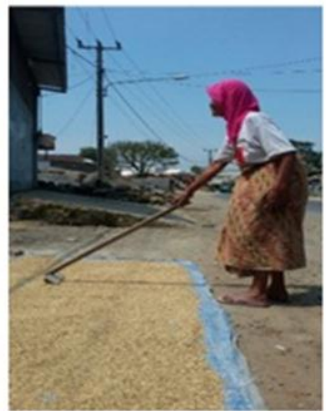

(i)

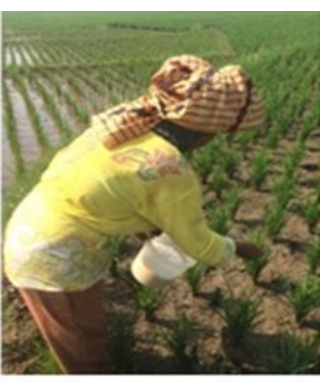

(e)

Figure 1. (a). Manual hoe for land clearing, (b) Grass cutting for land clearing, (c) Planting the rice, (d) Manual plow, (e) Giving fertilizer, (f) Harvesting, (g) Threshing, (h) Cleaning the rice from the straw, (i) Sun drying of rice

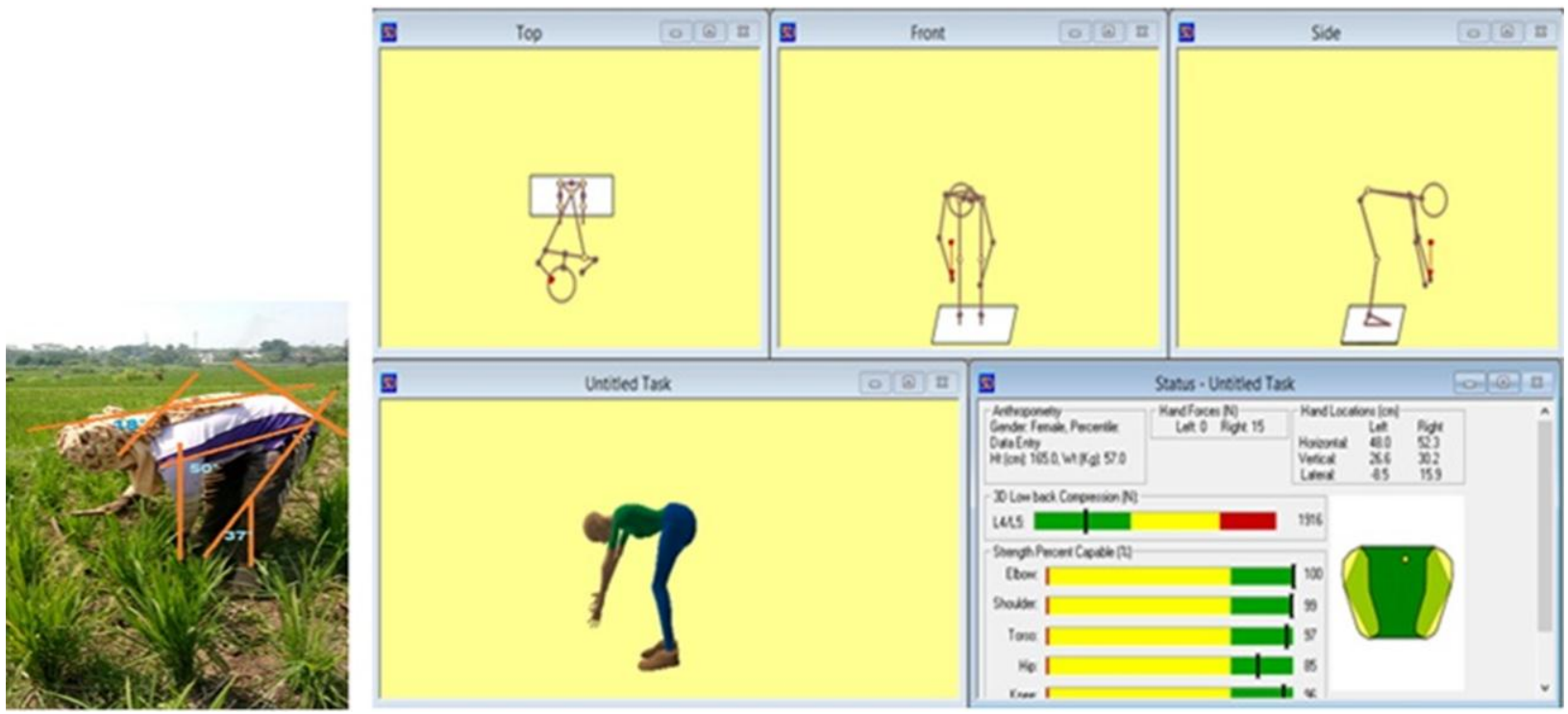

Figure 2. Example of postural analysis using 3D SSPP of grass cutting for land clearing. 


\begin{tabular}{|c|c|c|c|c|c|c|c|c|c|c|c|c|}
\hline \multirow{3}{*}{ Table A } & \multicolumn{12}{|c|}{ Neck } \\
\hline & & \multicolumn{4}{|c|}{1} & \multicolumn{3}{|c|}{ (2) } & \multicolumn{4}{|c|}{3} \\
\hline & Legs & 1 & 2 & 3 & 4 & 12 & 2) 3 & 3 4 & 41 & 2 & & 4 \\
\hline \multirow{5}{*}{$\begin{array}{l}\text { Trunk } \\
\text { Posture } \\
\text { Score }\end{array}$} & 1 & 1 & 2 & 3 & 4 & 1 & 23 & 34 & 3 & 3 & 5 & 6 \\
\hline & 2 & 2 & 3 & 4 & 5 & 3 & 45 & $\begin{array}{ll}5 & 6\end{array}$ & 4 & 5 & 6 & 7 \\
\hline & 3 & 2 & 4 & 5 & 6 & 4 & 5 & 7 & 5 & 6 & 7 & 8 \\
\hline & (4) & 3 & 5 & 6 & 7 & 5 & 6). & 78 & 6 & 7 & 8 & 9 \\
\hline & 5 & 4 & 6 & 7 & 8 & 6 & & 89 & 7 & 8 & 9 & 9 \\
\hline \multirow{3}{*}{\multicolumn{2}{|c|}{ Table B }} & \multicolumn{11}{|c|}{ Lower Arm } \\
\hline & & & & & & & & & & 2 & & \\
\hline & & & /ris & & (1) & 2 & & 3 & 1 & 2 & & 3 \\
\hline \multirow{6}{*}{$\begin{array}{l}\text { Uppe } \\
\text { Arm } \\
\text { Score }\end{array}$} & & & 1 & & 1 & 2 & & 2 & 1 & 2 & & 3 \\
\hline & & & 2 & & 1 & 2 & & 3 & 2 & 3 & & 4 \\
\hline & & & (3) & & (3) & 4 & & 5 & 4 & 5 & & 5 \\
\hline & & & 4 & & 4 & 5 & & 5 & 5 & 6 & & 7 \\
\hline & & & 5 & & 6 & 7 & & 8 & 7 & 8 & & 8 \\
\hline & & & 6 & & 7 & 8 & & 8 & 8 & 9 & & 9 \\
\hline \multirow{3}{*}{ Score A } & \multicolumn{12}{|c|}{ Table C } \\
\hline & \multicolumn{12}{|c|}{ Score B } \\
\hline & 1 & 2 & (3) & 4 & 5 & 6 & 7 & 8 & 9 & 10 & 11 & 12 \\
\hline 1 & 1 & 1 & 1 & 2 & 3 & 3 & 4 & 5 & 6 & 7 & 7 & 7 \\
\hline 2 & 1 & 2 & 2 & 3 & 4 & 4 & 5 & 6 & 6 & 7 & 7 & 8 \\
\hline 3 & 2 & 3 & 3 & 3 & 4 & 5 & 6 & 7 & 7 & 8 & 8 & 8 \\
\hline 4 & 3 & 4 & 4 & 4 & 5 & 6 & 7 & 8 & 8 & 9 & 9 & 9 \\
\hline 5 & 4 & 4 & 4 & 5 & 6 & 7 & 8 & 8 & 9 & 9 & 9 & 9 \\
\hline (6) & 6 & 6 & (6) & 7 & 8 & 8 & 9 & 9 & 10 & 10 & 10 & 10 \\
\hline 7 & 7 & 7 & 7 & 8 & 9 & 9 & 9 & 10 & 10 & 11 & 11 & 11 \\
\hline 8 & 8 & 8 & 8 & 9 & 10 & 10 & 10 & 10 & 10 & 11 & 11 & 11 \\
\hline 9 & 9 & 9 & 9 & 10 & 10 & 10 & 11 & 11 & 11 & 12 & 12 & 12 \\
\hline 10 & 10 & 10 & 10 & 11 & 11 & 11 & 11 & 12 & 12 & 12 & 12 & 12 \\
\hline 11 & 11 & 11 & 11 & 11 & 12 & 12 & 12 & 12 & 12 & 12 & 12 & 12 \\
\hline 12 & 12 & 12 & 12 & 12 & 12 & 12 & 12 & 12 & 12 & 12 & 12 & 12 \\
\hline
\end{tabular}

Figure 3. Example of REBA analysis for activity of grass cutting for land clearing

\section{Postural Analysis}

Postural analysis of Indonesian farmers can be seen in Figure 1 (a) - (i). The postural analysis was conducted based on the sequence of farm activities during rice plant. Example of postural analysis using 3D SSPP can be seen in Figure 2.

In addition, RULA and REBA analysis are applied to strengthen the $3 \mathrm{~d}$ SSPP result and to get priority of the ergonomic improvement in Indonesian rice farmers. The choice of RULA or REBA application is depending on the majority of body part involved in the activity. If the upper body part is mostly used in the activity, RULA is applied. If the whole body is involved in the activity, REBA is chosen. Example of REBA analysis for similar farm activity (cutting grass and land clearing) can be seen in Figure 3. For Table A, the score is obtained from the flexion of neck, trunk, and legs. Neck flexion $\left(18^{\circ}\right)$ is given a score of 2 , trunk flexion $\left(60^{\circ}\right)$ is given a score of 4 , and leg flexion $\left(20^{\circ}\right)$ is given a score of 2 . For Table B, the score is obtained from the flexion lower arm, upper arm, and wrist. Lower arm flexion $\left(50^{\circ}\right)$ is given a score of 3 , upper arm flexion $\left(11^{\circ}\right)$ is given a score of 1 , and wrist flexion $\left(<15^{\circ}\right)$ is given a score of 1 . The score for Table $\mathrm{C}$ is a result of mapping the score from Table A and Table B.

Recapitulation of the 3D SSPP and RULA/REBA analysis for each posture and task of Indonesian rice farmers can be seen in Table 3.

Application of ergonomics checkpoint in agriculture reveals the condition of Indonesian that needs improvement in particular in providing safety and health agriculture conditions. The most item that in urgent need of improvement is related to the most item in material storage and handling and welfare facilities. Items in material handling and storage point that needs urgent improvement are: (1) keep passageways clear and in good condition for the movement of people and materials (66.9 \%), (2) eliminate sudden height differences and holes on transport routes $(57.8 \%)$, (3) provide containers or baskets of appropriate sizes and with good grips to carry materials and farm products $(56.6 \%)$, (4) use charts, hand trucks, vehicles, boats, or animals to carry heavy materials (66.5\%), and (5) attach large enough wheels to carts and hand trucks to work effectively on field routes (53.4\%). Whereas items in welfare facilities point that needs urgent improvement are (1) build clean, hygienic toilets and washing facilities (74.5\%) and (2) provide first-aid equipment (64.1\%). The result of this study confirms the result of previous studies such as Kogi [17] and Fallahi et al. [3] who stated that most agriculture conditions are in need of improvement from the view of ergonomics, based on ergonomics checklist in agriculture proposed by ILO [26]. Overall, linking the result of this present study as reported in Table 1,2 , and 3; it can be seen that the ergonomics conditions that influence MSS in Indonesian farmers are mostly related to tools and material handling which are manifested in high risk of particular activities of Indonesian farmers.

Prevalence of musculoskeletal symptoms reveals that Indonesian farmers suffer from symptoms or injury in particular in the body part of shoulder (76.1 $\%$ ) and lower back (74.9 \%). This result is in line with the result of other studies and strengthens the fact of musculoskeletal symptoms or disorders among farmers in all area in the world, regardless the technology used in the farming process as can be seen in Table 4.

Based on the postural analysis, the highest load and tension among Indonesian farmers is in the grass cutting for land clearing, manual plow activity, followed by manual land clearing and threshing. The result of this study is supporting Meyers [12] who 
Table 3. Recapitulation of the 3D SSPP and RULA/REBA analysis among Indonesian farmers' activities

\begin{tabular}{llllr}
\hline No & \multicolumn{1}{c}{ Activities } & $\begin{array}{c}\text { REBA/RULA } \\
\text { score }\end{array}$ & \multicolumn{1}{c}{$\begin{array}{c}\text { Action } \\
\text { (including assessment) }\end{array}$} & $\begin{array}{c}\text { 3D SSPP } \\
\text { 3D low back compression (N) }\end{array}$ \\
\hline 1 & Manual hoe for land clearing & REBA 9 & Necessary soon & 318 \\
2 & Grass cutting for land clearing & REBA 8 & Necessary soon & 1916 \\
3 & Planting the rice & REBA 6 & Necessary & 221 \\
4 & Manual plow & REBA 10 & Necessary soon & 1784 \\
5 & Giving fertilizer & RULA 4 & Investigate further & 1358 \\
6 & Harvesting & REBA 4 & Necessary & 1493 \\
7 & Threshing & REBA 8 & Necessary soon & 1588 \\
8 & Cleaning the rice from the straw & RULA 5 & Investigate further and change soon & 933 \\
9 & Sun drying of rice & RULA 7 & Investigate and change immediately & 1184 \\
\hline
\end{tabular}

Table 4. Summary of studies associating with different ergonomics risk factors to different body part MSS

\begin{tabular}{|c|c|c|c|c|c|c|c|}
\hline \multirow{2}{*}{ Reference } & \multicolumn{7}{|c|}{ Musculoskeletal symptoms (MSS) } \\
\hline & neck & shoulder & elbow & hand wrist & low back & knee & ankle/foot \\
\hline NIOSH [5] & $\mathrm{v}$ & $\mathrm{v}$ & $\mathrm{v}$ & $\mathrm{v}$ & $\mathrm{v}$ & & \\
\hline Walker-Bone and Palmer [28] & $\mathrm{v}$ & $\mathrm{v}$ & & $\mathrm{v}$ & $\mathrm{v}$ & $\mathrm{v}$ & $\mathrm{v}$ \\
\hline Rosecrance et al. [29] & $\mathrm{v}$ & $\mathrm{v}$ & & $\mathrm{v}$ & $\mathrm{v}$ & & \\
\hline Davis and Kotowski [7] & $\mathrm{v}$ & $\mathrm{v}$ & $\mathrm{v}$ & $\mathrm{v}$ & $\mathrm{v}$ & $\mathrm{v}$ & $\mathrm{v}$ \\
\hline Osborne et al. [30] & $\mathrm{v}$ & $\mathrm{v}$ & & $\mathrm{v}$ & $\mathrm{v}$ & $\mathrm{v}$ & $\mathrm{v}$ \\
\hline Fathallah et al. [31] & $\mathrm{v}$ & $\mathrm{v}$ & $\mathrm{v}$ & $\mathrm{v}$ & $\mathrm{v}$ & & \\
\hline Lee [32] & & & & & $\mathrm{v}$ & $\mathrm{v}$ & \\
\hline $\mathrm{Ng}$ et al. [33] & & $\mathrm{v}$ & $\mathrm{v}$ & $\mathrm{v}$ & $\mathrm{v}$ & & \\
\hline This present study & $\mathrm{v}$ & $\mathrm{v}$ & $\mathrm{v}$ & $\mathrm{v}$ & $\mathrm{v}$ & $\mathrm{v}$ & $\mathrm{v}$ \\
\hline
\end{tabular}

mentioned three activities in farming that require improvement that is lifting an carrying heavy loads, repeated full-body bending, and high repetitive handwork (e.g., cutting etc).

Ergonomic checkpoint in agriculture proposed by ILO is used in this study because this checklist is proven to be useful in providing areas of improvement. The postural analysis method using the Nordic body questionnaire, RULA, and REBA are used in this study due to its practice and easy to use. The three methods are considered appropriate in observing postural analysis since the result of the three methods shows an inline result. However, it should be noted that there is an issue of inter-rater reliability (i.e, the possible different result according to different rater). Since the rater has been trained in a special session, it can be assumed that the reliability of the result of the postural analysis is considerable. Furthermore, the use of 3D SSPP has based on a consideration that this software gives detail information about a load of each part of the body. Compared to similar software in the postural analysis, 3D SSPP is more simple and easy to operate and analyze.

This study has several limitations worth noting. First, the sample is not representatives of Indonesian farmers since the sample come from West Java province only. Generalization of the result cannot be conducted, therefore further study covering other areas in Indonesia is important. Second, there is unbalance number between male and female partici- pants. It is obvious that male and female participants have different capabilities during activities, result in probable different musculoskeletal symptoms. However, since the analysis of the data in the present study also considers gender differences, these limitations do not influence the analysis.

Despite its limitation, this study can be seen as a first step in the analysis of Indonesian agriculture condition from the view of ergonomics. Coupled with the result of the high prevalence of musculoskeletal symptoms/disorders among Indonesian farmers based on both subjective (using Nordic body map) and objective analysis (using 3d SSPP), this study highlights the need to improve working condition and activities among Indonesian farmers. The improvement can be done through action-oriented training and campaign in which in the end it can enhance productivity as well as safety and health of Indonesian farmer and Indonesian agriculture. In the end, this study is expected to enhance safety and productivity in agriculture, which is along with another effort will enhance Indonesian food security. Globally, the result of this present study gives a significant contribution in completing the whole picture of agriculture condition in the world.

\section{Conclusion}

Indonesian agriculture is in a poor ergonomics condition and is associated with high musculoskeletal symptoms. The postural analysis also reveals a high risk of farmer activities. Such efforts in reducing 
musculoskeletal symptoms (MSS) should be conducted through improving working condition and activities among Indonesian farmers. The improvement can be done through action-oriented training and campaign in which in the end it can enhance productivity as well as safety and health of Indonesian farmers and Indonesian agriculture.

\section{Acknowledgment}

The author thanks Industrial Engineering Student of Bandung Institute of Technology (ITB) Indonesia, Introduction to ergonomics class 2017, K-02 who help in data collection.

\section{References}

1. Widyanti, A., Sunaryo, I., and Kumalasari, A. Reducing the Dependency on Rice as Staple Food in Indonesia: A Behavior Intervention Approach, International Journal of South East Asian Agricultural Association. 20(1), 2014, pp. 93-103

2. Susanto, T., Purwandari, R., and Wuryaningsih, W.R., Prevalence and Associated Factors of Health Problems among Indonesian Farmers. Chinese Nursing Research, 4(1), 2017, pp. 1-19.

3. Fallahi, H., Abbaspour-Fard, M.H., Azhari, A., Khojastehpour, M., and Nikkah, A., Ergonomics Assessment of Drivers in MF285 and MF399 Tractors during Clutching using Algometer. Information Processing in Agriculture, 3(1), 2016, pp. 54-60.

4. Susihono, W, Decreasing Musculoskeletal Complaints by Developing Product Design Based on Ergnomics Participatory, International Journal of Scientific and Engineering Research, 6, 2015, pp.176-179.

5. NIOSH, National Institute for Occupational Safety and Health, Simple Solutions: Ergonomics for Farm Workers. Report No. 2001-111, 153. Washington, D.C.: National Academy Press, 2001.

6. Helmkamp, J., and Lundstrom, W., Tractor Related Deaths among West Virginia Farmers, Annual Epidemiology, 12(7), 2002, p.510.

7. Davis, K.G., and Kotowski, S.E., Understanding the Ergonomic Risk for Musculoskeletal Disorders in the United States Agricultural Sector, American Journal of Industrial Medicine, 50(7), 2007, pp.501-511.

8. Min, D., Baek, S., and Park, H.W., Prevalence and Characteristics of Musculoskeletal Pain in Korean Farmers, Annual Rehabilitation Medic, 40(1), 2016, pp. 1-13.

9. Singh, S., and Arora, R., Ergonomic Intervention for Preventing Musculoskeletal Disorders among Farm Women. Journal of Agricultural Science. 1(2), 2010, pp. 61-71.
10. Oja, P., and Kwatra, S., An Ergonomic Study on the Assessment of Work Related Musculoskeletal Disorder Risks among Agriculture Workers of Uttarakhand, India. International Journal of Scientific and Engineering Research, 5(1), 2014, pp. 188-191.

11. Tella, B.A., Akinbo, S.R., Asafa, S.A., and Gbiri, C.A., Prevalence and Impacts of Low Back Pain among Peasant Farmers in South-west Nigeria. International Journal of Occupational Medicine and Environmental Health, 26, 2013, pp. 621627.

12. Meyers, J., Miles, J., Faucettt, J., Janowitz, I., Tejeda, D., Weber, E., Smith, R., and Garcia, L., Ergonomics Risk Factors for Musculoskeletal Disorder in Wine Grape Vineyard Work, 1988. Available at https://ag-ergo.ucdavis.edu/vineyar$\mathrm{djmm} /$ Accessed 20 June 2017

13. Grandjean, E., Fitting the Task to the Man: A Textbook of Occupational Ergonomics. $4^{\text {th }}$ edition. London: Taylor and Francis, 1988.

14. Kirkhorn, S.R., and Earle-Richardson, G., Ergonomic Risks and Musculoskeletal Disorders in Production Agriculture: Recommendations for Effective Research to Practice. Journal of Agromedicine, 15(3), 2010, pp. 281-299.

15. Kawakami, T., and Kogi, K., Ergonomics Support for Local Initiative in Improving Safety and Health at Work: International Labor Organization Experiences in Industrially Developing Countries. Ergonomics. 48(5), 2005, pp. 581-590.

16. Budnick, P., Kogi, K., and O'Neill, D., Examples of Practical Ergonomics in Industrially Developing Countries. Ergonomics, 20, 2012, pp. 5-11

17. Kogi, K., Advances in Participatory Occupational Health Aimed at Good Practices in Small Enterprises and the Informal Sector, Industrial Health, 44(1), 2016, pp. 31-34.

18. Chaffin, D.B., Andersson, G.B.J., and Martin, B.J., Occupational Biomechanics. $4^{\text {th }}$ edition. New York: Willey, 2006.

19. Kourinka, I., Jonsson, B., Kilbom, A., Vinternerg, H., Biering-Sorensen, F., Andersson, F., and Jorgesen, K., Standardised Nordic Questionnaires for the Analysis of Musculoskeletal Symptoms. Applied Ergonomics, 18(3), 1987, pp. 233-237.

20. Hignett, S., and McAtamney, L., Rapid Entire Body Assessment. Applied Ergonomics, 31(2), 2000, pp. 201-205.

21. McAtamney, L., and Corlett, E., N., RULA: A Survey Method for the Investigation of Work-related Upper Limb Disorders. Applied Ergonomics, 24(2), 1993, pp. 91-99.

22. 3D SSPP software, University of Michigan, USA, available at https://c4e.engin.umich.edu/ tools-services/3dsspp-software/

23. BPS, Indonesian statistical Bureau (Badan Pusat Statistik), 2016. Available at www.bps.go.id Accessed 24 May 2017. 
24. Wibowo, R.K.K., and Soni, P., An Ergonomics Analysis of Indonesian Farmers in using Agricultural Hand Tools in Relation to Their Comfort and Satisfaction. International Journal of research in Agricultural Sciences, 4, 2017, pp. 15-32.

25. Fuglie, K.O. Productivity Growth in Indonesia Agriculture, 1961-2000. 47th Annual Conference of the Australian Agricultural and Resource Economics Society, February 12-14, 2003.

26. ILO, International Labor Office, Ergonomic Checkpoints in Agriculture: Practical and Easyto-implement Solutions for Improving Safety, Health, and Working Conditions in Agriculture, 2012, Available at www.ilo.org/wcmsp5/groups/ public/---dgreports/--.../wcms_168042.pdf Accessed 20 January 2017.

27. IRRI, International Rice Research Institute, Available at http:/www.knowledgebank.irri.org/ step-by-step-production. Accessed 24 May 2017.

28. Walker-Bone, K., and Palmer, K.T., Musculoskeletal Disorders in Farmer and Farm Qorkers, Occupational Medicine, 52, 2002, pp. 441-450.
29. Rosecrance, J., G. Rodgers, and L. Merlino. Low back pain and musculoskeltal symptoms among Kansas farmers. American Journal of Industrial Medicine. 49, 2006, pp.547-556.

30. Osborne, A., C. Blake, B.M. Fullen, D. Meredith, J. Phelan, J. McNamara, and C. Cunningham. Prevalence of musculoskeletal disorders among farmers: A systematic review. American Journal of Industrial Medicine. 55, 2012, pp.143-158.

31. Fathallah, F.A. Musculoskeletal Disorders in Labor-intensive Agriculture. Applied Ergonomics, 4, 2010, pp. 738-743.

32. Lee, S-J., and Park, H-J. Work-related Musculoskeletal Disorders among Agricultural Workers. Journal of the Ergonomics Society of Korea, 30(4), 2011, pp.525-534.

33. Ng, Y.G., M.T.S. Bahri, M.Y.I. Syah, I. Mori, and Z. Hashim, Ergonomics Observation: Harvesting Tasks at Oil Palm Plantation, Journal of Occupational Health. 55, 2013,pp. 405-414. 